\title{
The acute metabolic and cardiovascular effects of mirabegron in healthy individuals
}

Rebecca K.C. Loh, Melissa F. Formosa, Andre La Gerche, Anne T. Reutens, Bronwyn A. Kingwell and Andrew L. Carey ${ }^{1,2}$

1. Metabolic and Vascular Physiology Laboratory, Baker Heart and Diabetes Institute, P.O. Box 6492, Melbourne, VIC 3004, Australia

2. Department of Physiology, Monash University, Clayton, Melbourne, VIC, Australia.

3. Sports Cardiology Laboratory, Baker Heart and Diabetes Institute, Melbourne, VIC, Australia

4. Clinical Diabetes and Epidemiology, Baker Heart and Diabetes Institute, Melbourne, VIC, Australia

Short running title: Dose-dependent effects of ${ }^{2} 3$-adrenoceptor agonism

Word count:

Abstract: 246

Main manuscript: 3,526

References: 40

Tables: 1

Figures: 4

\section{Corresponding authors}

Andrew L Carey* and Bronwyn A Kingwell

Metabolic and Vascular Physiology

Baker Heart and Diabetes Institute

P.O. Box 6492, Melbourne, VIC 3004, Australia

E-mail: andrew.carey@baker.edu.au; bronwyn.kingwell@baker.edu.au

*correspondence and reprint requests

This is the author manuscript accepted for publication and has undergone full peer review but has not been through the copyediting, typesetting, pagination and proofreading process, which may lead to differences between this version and the Version of Record. Please cite this article as doi: $10.1111 /$ dom.13516

This article is protected by copyright. All rights reserved. 


\begin{abstract}
Aims: ${ }^{2} 3$-adrenoceptor activation represents a potential target for increased energy expenditure through brown adipose tissue (BAT) thermogenesis. The purpose of this study was to quantify acute energy expenditure, supraclavicular skin temperature and cardiovascular responses to 4 doses of the ${ }^{2} 3$-adrenoceptor agonist, mirabegron.

Materials and methods: Seventeen individuals (11 male, 6 female) participated in this ascending dose study, receiving single 50,100, 150 and $200 \mathrm{mg}$ of mirabegron on 4 separate days with 3-14 days wash-out between each dose. All variables were measured each visit from baseline to $180 \mathrm{~min}$ post mirabegron treatment. To determine BAT thermogenic efficacy at each dose, baseline energy expenditure and supraclavicular skin temperature were compared to $180 \mathrm{~min}$ post mirabegron treatment. To examine safety, changes in cardiovascular variables at 100,150 and $200 \mathrm{mg}$ were compared to the standard clinical dose of $50 \mathrm{mg}$.
\end{abstract}

Results: Energy expenditure significantly increased after $100(35.6 \pm 5.4 \mathrm{kj} / \mathrm{hr})$ and $200 \mathrm{mg}$ $(35.6 \pm 13.1 \mathrm{kj} / \mathrm{hr})$ doses $(p \mathrm{~d} 0.05)$, and trended towards an increase after 150mg $(24.1 \pm 13.6$ $\mathrm{kj} / \mathrm{hr})$. Supraclavicular skin temperature increased after $50\left(0.22 \pm 0.1^{\circ} \mathrm{C}\right), 100\left(0.30 \pm 0.1^{\circ} \mathrm{C}\right)$ and 150mg $\left(0.29 \pm 0.1^{\circ} \mathrm{C}\right)$ mirabegron $(p \mathrm{~d} 0.05)$. The change in systolic blood pressure was greater after $150(7.1 \pm 1.3 \mathrm{mmHg})$ and $200 \mathrm{mg}(9.3 \pm 1.9 \mathrm{mmHg})$ doses compared to $50 \mathrm{mg}$ $(2.2 \pm 1.3 \mathrm{mmHg}, p \mathrm{~d} 0.05)$. The change in heart rate was greater after $200 \mathrm{mg}(9.0 \pm 2.2 \mathrm{bpm})$ compared to $50 \mathrm{mg}(2.9 \pm 1.4 \mathrm{bpm}, p \mathrm{~d} 0.05)$.

Conclusions: A 100mg dose of mirabegron increases energy expenditure and supraclavicular skin temperature in $\mathrm{a}^{2} 3$-adrenoceptor-specific manner without off-target elevations in blood pressure or heart rate observed at higher doses.

Trial registration: (anzctr.org.au): ACTRN12617000542392

Keywords: ${ }^{2} 3$-adrenoceptor agonist, adrenergic receptor, brown adipose tissue, energy expenditure, sympathomimetic, obesity 


\section{Introduction}

Brown adipose tissue (BAT) has been proposed as a potential target for anti-obesity therapy due to its primary function of heat production during cold exposure and associated elevation in energy expenditure. ${ }^{1}$ BAT recruitment and thermogenesis ${ }^{2,}{ }^{3}$ is mediated by the ${ }^{2} 3$ adrenoceptor, which is highly expressed in brown adipocytes and the detrusor muscle and urothelium of the bladder. ${ }^{4,5}$ Soon after discovery of the ${ }^{2} 3$-adrenoceptor, it became the focus of pharmacological targeting for potential weight reduction in humans. Though early agents were successful at eliciting weight loss and lowering glycaemic index in rodent models ${ }^{6-8}$ they failed in human trials due to poor selectivity, bioavailability and pharmacokinetic properties for the human ${ }^{2} 3$-adrenoceptor. ${ }^{6,9}$ Moreover, variations in BAT ${ }^{2} 3$-adrenoceptor expression between species may have contributed to lack of efficacy. ${ }^{10,11}$

Recently, a new generation of ${ }^{2} 3$-adrenoceptor agonists with good bioavailability and high in vitro binding specificity was developed for the treatment of overactive bladder syndrome (OAB). ${ }^{12}$ Mirabegron was approved by the USA Food and Drug Administration (FDA) in 2012 for treatment of $\mathrm{OAB}$. In the first attempt to translate novel ${ }^{2} 3$-adrenoceptor agonists to the study of human BAT, Cypess et al. ${ }^{13}$ demonstrated an increase in whole body energy expenditure and BAT glucose uptake after a single $200 \mathrm{mg}$ mirabegron dose, to a degree that matched responses to cold exposure. ${ }^{13}$ However, this dose is higher than the current therapeutic dose approved for OAB therapy $(50 \mathrm{mg})$. As expected, based on randomised clinical trials (RCT) during development for $\mathrm{OAB},{ }^{14-17}$ the $200 \mathrm{mg}$ dose significantly increased systolic blood pressure by $\sim 10 \mathrm{mmHg}$. This is due to loss of selectivity for the ${ }^{2} 3-$ 
adrenoceptor at this dose, such that mirabegron indirectly activates ${ }^{2} 1$-adrenoceptors that are widely expressed throughout various organs, particularly the cardiovascular system. ${ }^{18}$ Though higher doses ( 200 mg) are effective at activating BAT, prolonged adrenergic stimulation of the cardiovascular system would potentially elevate risk for conditions such as hypertension, making chronic use at such doses unviable. ${ }^{19}$ Additionally, our lab previously demonstrated that chronic pan- ${ }^{2}-\mathrm{AR}$ agonism may reduce BAT function. ${ }^{20}$

Although $50 \mathrm{mg}$ is the highest approved therapeutic dose for OAB, RCTs with mirabegron doses up to $100 \mathrm{mg}$ /day for at least 12 months had a good safety profile. ${ }^{21}$ Nevertheless, it remains unknown whether doses higher than $50 \mathrm{mg}$ but lower than $200 \mathrm{mg}$ can increase energy expenditure and BAT activity. Hence, the aim of the present study was to determine the effects of multiple doses of mirabegron $(50,100,150$, and $200 \mathrm{mg}$ ) on whole body energy expenditure and BAT heat production, and to compare cardiovascular responses between the approved maximum therapeutic dose of $50 \mathrm{mg}$ to higher mirabegron doses (100, 150 and 200 mg) in young healthy adults. 


\section{Materials and Methods}

This study was approved by the Alfred Health Human Ethics Committee and performed in accordance with the Declaration of Helsinki, Seventh Revision, 2013. All participants provided written, informed consent. Study data were collected and managed using REDCap electronic data capture tools hosted at Baker Heart and Diabetes Institute. ${ }^{22}$

\section{Participants}

Twenty-one participants (aged 18-35 years, body mass index (BMI) d30 kg/m², free from cardiovascular disease and diabetes, unmedicated, non-smokers) consented to participate in this study, conducted between April and November 2017. Four participants withdrew from the study prior to participation in the first drug treatment trial. Therefore, 17 participants were included in the data analyses (CONSORT recruitment diagram shown in Figure 1).

\section{Study design}

This study was a non-randomised, multiple ascending dose pilot study. Participants visited the research facility on a maximum of five occasions. On the first laboratory visit, a general medical screen was conducted and baseline physical (height, weight, waist:hip ratio, blood pressure, body composition via dual-energy x-ray absorptiometry) and biochemical (glucose and insulin) characteristics were measured. The following four visits each involved taking a single dose of 50,100, 150 or $200 \mathrm{mg}$ of mirabegron in an ascending dose order. The washout period between each mirabegron dose was 3-14 days. Baseline and post mirabegron 
administration physiological variables were measured as described below.

This article is protected by copyright. All rights reserved. 


\section{Medical screening}

After obtaining informed consent, a physical assessment was conducted, including height, weight, waist:hip ratio, blood pressure via automated oscillometry (Omron Healthcare, Melbourne, VIC, Australia) and body composition via dual-energy x-ray absorptiometry (GE Lunar iDXA, Getz Healthcare, Lane Cove, NSW, Australia). Fasting blood glucose and insulin (Alfred Health, Department of Pathology, Melbourne, Australia) were measured and a general medical health assessment, including electrocardiography (ECG), were conducted by a physician.

\section{Drug administration trials}

Participants were requested to fast from 2200 hours the night before and refrain from alcohol, caffeine (tea, coffee, caffeinated soft drinks) and vigorous exercise 48 hours prior to each visit. They arrived at the laboratory at approximately 0800 hours, voided and were dressed in hospital scrubs and socks. Skin temperature sensors (iButtons Maxim, San Jose, CA, USA) were placed on the skin as described below with Micropore tape (3M Health Care, St Paul, MN, USA) for continuous recording of skin temperature (reported data-points include the mean of the 15 min-by-min recordings preceding each time-point). Participants then rested for $90 \mathrm{~min}$ in a supine position covered by a blanket. For all trials, the laboratory was maintained at $24-25^{\circ} \mathrm{C}$ and monitored throughout (Davis Vantage Weather Station, Davis Instruments, Hayward CA, USA).

This article is protected by copyright. All rights reserved. 
After resting for $90 \mathrm{~min}$, energy expenditure (indirect calorimetry) was measured. Baseline blood pressure and heart rate were recorded as the mean of four separate measurements between 5 and 30 min preceding drug administration. Immediately following this, the appropriate dose of mirabegron was administered with water. Over the following $180 \mathrm{~min}$, blood pressure, heart rate and skin temperature were measured every 15 min and energy expenditure was measured at 60,120 and 180 min after drug ingestion.

\section{Biochemical analyses}

During screening, blood was collected in an appropriate preservative and glucose and insulin measured immediately to clinical diagnostic standard (Alfred Hospital, Department of Pathology).

\section{Energy expenditure}

Energy expenditure was measured as previously described using indirect calorimetry ${ }^{20,23,24}$ for 20-30 min at each time-point, with the mean of the final $\sim 15$ min of recording used for data reporting.

\section{Supraclavicular skin temperature}

Direct measurement of BAT activity requires use of positron emission tomography/computed tomography $(\mathrm{PET} / \mathrm{CT})$ techniques, which involve radiation exposure and prohibit multiple scans within an individual. To overcome this limitation, we employed iButton temperature sensors and recorders to assess supraclavicular skin temperature (Thermodata, Eight Miles 
Plains, QLD, Australia) as a surrogate indicator of BAT activity. These devices have been previously validated as representative of BAT activity in response to cold exposure in humans. ${ }^{25,26}$ Several PET/CT imaging studies including ours ${ }^{20,23,24}$ along with studies which have employed iButton sensors ${ }^{25-27}$ indicate that a prominent BAT depot lies close to the skin beneath the supraclavicular fossa. The size, shape and specific location of this BAT depot exhibits inter-individual variability, with prominent neck musculature also underlying the skin in this region. Two sensors were therefore positioned in each supraclavicular fossa; they were placed immediately above the clavicle, one between the sternal and clavicular heads of the sternocleidomastoid muscle, and the other, lateral to the clavicular head of this muscle. Supraclavicular skin temperature was reported as the mean of recordings from these sensors.

\section{Blood pressure and heart rate}

At each time-point, blood pressure and heart rate were measured 3 times at $\sim 30$ second intervals using an automated oscillometric device (Omron Healthcare, Melbourne, VIC, Australia) and the average of the three measurements reported at each time-point and used for statistical analyses where indicated. Since the purpose of the trial was to determine dosespecific efficacy and safety for mirabegron, an increase in mean systolic blood pressure of $>10 \mathrm{mmHg}$ for all values recorded at 120,150 and $180 \mathrm{~min}$ after mirabegron treatment in any trial was deemed to have induced unacceptable off-target effects. In such instances, participants were excluded from remaining trial/s.

\section{Statistical analyses}


The peak concentration of mirabegron in the blood over the proposed dose range has been previously reported to occur approximately $180 \mathrm{~min}$ after oral dosing, ${ }^{28}$ therefore, this timepoint was selected for key statistical comparisons. All variables were checked for normality prior to analyses.

\section{Efficacy.}

Energy expenditure and skin temperature data were normally distributed. To determine whether individual mirabegron doses altered energy expenditure and supraclavicular skin temperature, variables were analysed using a Paired Student's t-test comparing baseline (0 min) with 180 min post mirabegron ingestion within each dose.

\section{Safety.}

The change in cardiovascular variables were defined as the change from baseline to $180 \mathrm{~min}$ after drug ingestion. Because blood pressure and heart rate data were not normally distributed, non-parametric analyses were employed. Safety of each of 100, 150 and $200 \mathrm{mg}$ doses was assessed based on comparison with the standard clinical dose of $50 \mathrm{mg}$. KruskalWallis ANOVA followed by Bonferroni-corrected Conover-Iman post-hoc analysis was used to compare groups.

Statistical analyses were performed using Graphpad Prism (v7; GraphPad Software, La Jolle, CA, USA) or Stata/SE 14.0 (StataCorp LP, College Station, TX, USA). Data are expressed as 
mean \pm SEM with $p \mathrm{~d} 0.05$ considered significant. Trends towards significance were accepted as $p \mathrm{~d} 0.1$.

This article is protected by copyright. All rights reserved. 


\section{Results}

\section{Study population}

Baseline characteristics for the cohort are reported in Table 1 (11 males and 6 females, age $24 \pm 1$ years, BMI $23 \pm 1 \mathrm{~kg} / \mathrm{m}^{2}$ ). Seventeen, thirteen, twelve and ten participants completed the 50, 100, 150 and $200 \mathrm{mg}$ trials, respectively. Only one participant was excluded due to systolic blood pressure elevation of $>10 \mathrm{mmHg}$, which occurred during the $150 \mathrm{mg}$ trial (Figure

1).

\section{Energy expenditure}

Figure $2 \mathrm{a}$ reports the rates of energy expenditure at each time-point throughout each trial. These data validates prior trials in reporting the occurrence of peak responses to mirabegron at approximately $180 \mathrm{~min}$ post oral administration. Figure $2 \mathrm{~b}$ shows energy expenditure at baseline ( $0 \mathrm{~min})$ and $180 \mathrm{~min}$ post mirabegron ingestion for each dose. Mirabegron doses of 100 and $200 \mathrm{mg}$ significantly increased ( $p \mathrm{~d} 0.05$ ) energy expenditure (by $35.6 \pm 5.4$ and $35.6 \pm 13.1 \mathrm{kj} / \mathrm{hr}$, respectively), while $150 \mathrm{mg}(24.1 \pm 13.6 \mathrm{kj} / \mathrm{hr})$ displayed a similar trend (pd0.1). Energy expenditure $180 \mathrm{~min}$ post mirabegron ingestion was not significantly different to baseline in response to $50 \mathrm{mg}$ of mirabegron $(12.7 \pm 12.0 \mathrm{kj} / \mathrm{hr})$.

\section{Skin temperature}

Figure $3 \mathrm{a}$ shows skin temperature at $30 \mathrm{~min}$ intervals throughout the trials. Figure $3 \mathrm{~b}$ reports skin temperature at baseline $(0 \mathrm{~min})$ and $180 \mathrm{~min}$ after each dose of mirabegron. Supraclavicular skin temperature, representative of regional BAT heat production, 
significantly increased $(p \mathrm{~d} 0.05)$ after 50,100 , and $150 \mathrm{mg}$ of mirabegron $(0.22 \pm 0.1,0.30 \pm 0.1$ and $0.29 \pm 0.1{ }^{\circ} \mathrm{C}$ respectively). In contrast, supraclavicular temperature $180 \mathrm{~min}$ post mirabegron ingestion was not significantly different to baseline in response to $200 \mathrm{mg}$ $\left(0.03 \pm 0.2^{\circ} \mathrm{C}\right)$ mirabegron.

\section{Blood pressure and heart rate}

The time-course and change between baseline $(0 \mathrm{~min})$ and $180 \mathrm{~min}$ for systolic and diastolic blood pressure and heart rate in response to mirabegron are shown in Figure 4. The change in systolic pressure was not different between the $50(2.2 \pm 1.3 \mathrm{mmHg})$ and $100 \mathrm{mg}(5.2 \pm 1.0$ $\mathrm{mmHg})$ doses, but was significantly higher $(p \mathrm{~d} 0.05)$ after $150 \mathrm{mg}(7.1 \pm 1.3 \mathrm{~mm} \mathrm{Hg})$ and 200 $\mathrm{mg}(9.3 \pm 1.9 \mathrm{mmHg})$. For the three higher doses, the change in diastolic pressure was not different to $50 \mathrm{mg}$. The change in heart rate after $100 \mathrm{mg}(5.3 \pm 1.3 \mathrm{bpm})$ and $150 \mathrm{mg}(7.4 \pm 1.4$ bpm) were not different to $50 \mathrm{mg}(2.9 \pm 1.4 \mathrm{bpm})$, but was significantly greater after $200 \mathrm{mg}$ (9.0 $\pm 2.2 \mathrm{bpm}, p \mathrm{~d} 0.05)$ compared to $50 \mathrm{mg}$.

This article is protected by copyright. All rights reserved. 


\section{Discussion}

This study is the first to investigate the acute effects of ascending doses of mirabegron on both energy expenditure and cardiovascular end-points. The data indicate that mirabegron may be efficacious at increasing energy expenditure without significant risk of off-target cardiovascular effects at a dose of $100 \mathrm{mg}$ in healthy, young individuals. Significant increases in blood pressure at higher doses $(150$ and $200 \mathrm{mg})$ demonstrate these to be unsuitable for chronic administration. Although all doses except for $200 \mathrm{mg}$ increased supraclavicular temperature, we cannot definitively conclude that this was due to increased BAT activity since the lack of change after the $200 \mathrm{mg}$ dose contrasts with a previous report showing this dose to increase directly measured BAT activity. ${ }^{13}$

\section{Assessment of efficacy}

\section{Energy expenditure}

Cypess et al. demonstrated that a single $200 \mathrm{mg}$ dose of mirabegron increases energy expenditure, which also correlated with BAT activity measured via $\left[{ }^{18} \mathrm{~F}\right]$-fluorodeoxyglucose (FDG)-PET/CT. ${ }^{13}$ In this prior study, energy expenditure increased by approximately $13 \%$, which is similar to the $16 \%$ increase observed in the present study after the $200 \mathrm{mg}$ dose. However, due to off-target cardiovascular effects induced in this and other clinical trials, ${ }^{15,28}$ $200 \mathrm{mg}$ would not be a viable chronic therapeutic dose. Notably, however, our study further demonstrates that after both lower mirabegron doses of 100 and $150 \mathrm{mg}$, energy expenditure increases by $15 \%$ and $11 \%$, respectively, but only by $7 \%$ after the $50 \mathrm{mg}$ dose. 


\section{Supraclavicular skin temperature}

We estimated BAT activity in response to several doses of mirabegron by monitoring skin temperature in the supraclavicular fossa. A surrogate measure was necessary, since measurement of BAT activity via $\left[{ }^{18} \mathrm{~F}\right]-\mathrm{FDG}$ PET/CT would have resulted in unjustifiably high exposure of participants to ionising radiation as a result of the multi-dose study design. Previous studies have reported significant correlations between changes in supraclavicular skin temperature and BAT glucose uptake via $\left[{ }^{18} \mathrm{~F}\right]-\mathrm{FDG}$ PET/CT after mild-cold exposure ${ }^{25}$, ${ }^{27}$ and glucose-stimulated post-prandial thermogenesis. ${ }^{26}$ Together, these studies provide a rational basis for estimation of BAT activity by measuring skin temperature immediately external to a major BAT depot.

The change in supraclavicular skin temperature in the present study across all doses of mirabegron was approximately $0.2-0.3^{\circ} \mathrm{C}$, with the notable exception of the $200 \mathrm{mg}$ dose. The $0.2-0.3^{\circ} \mathrm{C}$ increase parallels prior studies of mild cold exposure ${ }^{25}$ or a glucose load. ${ }^{26}$ However, the present study and these two prior studies ${ }^{25,26}$ differ from a further $\operatorname{study}^{27}$ of mild cold exposure, where cold exposure decreased supraclavicular skin temperature, but that supraclavicular skin temperature remained significantly positively associated with higher BAT activity measured via $\left[{ }^{18} \mathrm{~F}\right]-\mathrm{FDG}$ PET/CT. The two studies of mild cold exposure employed different methods of cooling: water-perfused mattresses in a $\sim 24^{\circ} \mathrm{C}$ room $^{25}$ versus an air-cooled $\left(\sim 15^{\circ} \mathrm{C}\right)$ environment. ${ }^{27}$ This clearly demonstrates that prevailing environmental conditions can influence regional skin temperature and consequently the pattern, and potentially likelihood, of detecting a change in supraclavicular skin temperature. 
While supraclavicular skin temperature was not increased after the $200 \mathrm{mg}$ dose, it is highly likely that BAT activity did increase in response to this dose. Nevertheless, in absence of a placebo/no drug treatment trial, we cannot definitively determine whether BAT activity increased as a result of mirabegron treatment. Conversely, because a $200 \mathrm{mg}$ dose is known to increase BAT activity measured via $\left[{ }^{18} \mathrm{~F}\right]-\mathrm{FDG} \mathrm{PET} / \mathrm{CT},{ }^{13}$ all doses within the range of 50 $\mathrm{mg}$ to $200 \mathrm{mg}$ are likely to have efficacy in this regard. This has been supported by a recent study examining single 50 and $200 \mathrm{mg}$ doses of mirabegron administered to 12 healthy individuals. ${ }^{29}$ A dose-dependent response with BAT activity was evident with half the participants showing either no change or a negligible increase after the $50 \mathrm{mg}$ dose, and only one non-responder to the $200 \mathrm{mg}$ dose. These new data ${ }^{29}$ combined with the present study suggest further studies are required to determine BAT activity responses for mirabegron doses between 50 and $200 \mathrm{mg}$.

Increased off-target effects with $200 \mathrm{mg}$ mirabegron are well-described. ${ }^{28,30}$ The complex regulation of skin and organ blood flow resulting from non-specific adrenergic activation induced by such doses would be expected to alter skin blood flow in a manner which would invalidate it as a measure of BAT activity. Thus, supraclavicular temperature may not be a sensitive index of BAT activity in response to agents that affect skin blood flow, including high mirabegron doses and/or other sympathomimetic drugs, particularly at doses in which receptor specificity is reduced. 


\section{Cardiovascular safety}

Clinical trials involving chronic treatment (3-12 month) with mirabegron in doses ranging from 25-100 mg have consistently demonstrated that these doses do not result in increased incidence of tachycardia, blood pressure, ECG changes or any cardiovascular events. ${ }^{14,15,17}$, 28, 30, 31 Our observation of statistically significant elevations in blood pressure for the two higher (150 and $200 \mathrm{mg}$ ) but not lower (50 and $100 \mathrm{mg}$ ) mirabegron doses are congruent with the literature with regard to mirabegron-related increases in cardiovascular responses from large RCTs, ${ }^{14}, 15,17,28,30,31$ and the study by Cypess et al. ${ }^{13}$ This could be indicative of progressive non-selectivity for ${ }^{2} 3$-adrenoceptors, to include activation of other adrenoceptors as doses increase. Recently, mirabegron's effect on cardiac contractile force was reported to arise from indirect targeting of ${ }^{2} 1$-adrenoceptors. ${ }^{32}$ This mechanism involves noradrenaline transporter uptake of mirabegron into cardiac sympathetic nerve terminals, subsequently causing a release of noradrenaline which activates ${ }^{2} 1$-adrenoceptors. This mechanism explains the increase in heart rate after the $200 \mathrm{mg}$ dose. ${ }^{33}$ This ionotropic action of mirabegron is similar to the sympathomimetic ephedrine; both compounds share a phenylethanolamine structure, which is sensitive to sympathetic nerve terminal uptake and induction of noradrenaline release. ${ }^{32,34,35}$ The subsequent result is an increase in the rate and/or force of contraction of the heart, thereby increasing blood pressure. ${ }^{36,37}$

In addition to mirabegron's indirect effects on the ${ }^{2} 1$-adrenoceptor, it is also suggested to have a high binding affinity with muscarinic receptors and to antagonise $\alpha 1$-adrenoceptors in 
human and isolated rat tissue binding/functional experiments. ${ }^{38-40}$ This dual mechanism is thought to be responsible for smooth muscle relaxation in the urethra, explaining efficacy in treating $\mathrm{OAB}$. Mirabegron s preferential selectivity for the ${ }^{2} 3$-adrenoceptor relative to ${ }^{2} 1 / 2$ adrenoceptors accounts for the relatively small increase in blood pressure compared with pan2 agonists. In addition to this, at higher mirabegron doses, partial ${ }^{2} 2$-adrenoceptor agonistand $\alpha 1$-adrenoceptor antagonist-mediated dilatation of small blood vessels may counteract increases in cardiac output. This could further contribute to mirabegron-induced increases in blood pressure being considerably lower than previously reported responses to high doses of non-selective sympathomimetics. ${ }^{13,20,23,41}$

We have proposed, based on the present study and prior phase II and III clinical trial data, ${ }^{30}$ that 50 and $100 \mathrm{mg}$ mirabegron doses do not elevate cardiovascular risk. It is evident based on individual responses presented in Figure 4 that significant inter-individual variability exists regarding cardiovascular responses to each dose. For example, our data demonstrate that the two lower doses both increase systolic blood pressure and heart rate as much as the mean for the two higher doses. Conversely, some individuals experience virtually no increase in blood pressure and/or heart rate in response to the two higher doses. Importantly, during rest periods of similar duration at the same time of day ( $\sim 3$ hours during the morning), systolic blood pressure increases without any intervention, as we have previously reported, ${ }^{42}$ by approximately the same or greater amounts $(\sim 5 \mathrm{mmHg})$ than those reported in the present trial after $50 \mathrm{mg}$ and $100 \mathrm{mg}$ doses. Therefore, since the $100 \mathrm{mg}$ dose increased energy expenditure without increasing blood pressure to a greater level than the $50 \mathrm{mg}$ dose, future 
long-term trials investigating the effects of mirabegron on metabolism should consider dosing at $100 \mathrm{mg}$.

\section{Clinical implications}

The development of selective ${ }^{2} 3$-adrenoceptor agonists for treatment of $\mathrm{OAB}$ has reinvigorated interest in examining this mechanism for BAT-directed obesity therapy. New agonists have overcome both poor bioavailability and binding with the human ${ }^{2} 3$ adrenoceptor, though comprehensive examination of the concurrent effects of these agents on metabolic and cardiovascular function have not been conducted. Our study highlights the importance of conducting further investigations that are dedicated to understanding the impact of ${ }^{2} 3$-adrenoceptor agonists on human BAT and whole body energy metabolism, and extend beyond doses approved for OAB therapy. Trials dedicated to examining the effect of mirabegron on $\mathrm{OAB}$ patients have included overweight and/or obese individuals, however no evidence has been presented to indicate whether there are concerns regarding either efficacy or safety in these specific populations. Follow up studies of new ${ }^{2} 3$-adrenoceptor agonists on BAT physiology should prioritise trials focused on obese individuals. The present study does not offer insight regarding this population, a group with a high prevalence of cardiovascular comorbidities and dysregulated sympathetic nervous system responsiveness.

\section{Limitations}

This study was a pilot trial directed to determine the physiological responses to several doses of mirabegron against the current maximum on-label therapeutic dose of $50 \mathrm{mg}$. While this allowed comparison to higher doses which may prove efficacious, we are unable to define the 
absolute magnitude of these dose effects due to the absence of a placebo/no treatment control. Additionally, we were not able to employ PET/CT imaging to measure BAT activity due to the high level of radiation exposure which would have been associated with the 4 treatment conditions studied. Future studies designed with fewer doses may permit BAT assessment using the current gold-standard of either PET/CT imaging or PET combined with magnetic resonance imaging, ideally incorporating glucose and lipid tracers that could enable assessment of whole tissue oxidative metabolism.

\section{Conclusion}

In the ongoing, but thus far unfruitful search for safe and effective drugs to increase BAT energy expenditure in humans, ${ }^{2} 3$-adrenoceptor agonists remain of interest and are arguably the most promising drug class for this purpose. While questions remain regarding the ${ }^{2} 3$ adrenoceptor specificity of mirabegron, based on the present study and several large clinical trials, a $100 \mathrm{mg}$ dose of mirabegron should be considered safe to proceed to longer trials with small cohorts to examine the potential for safety and efficacy in promoting energy expenditure in future studies. Further in vivo human trials examining the pharmacology and physiology of mirabegron and other ${ }^{2} 3$-adrenoceptor agonists are warranted.

This article is protected by copyright. All rights reserved. 
Acknowledgements: We thank our research participants for their time and interest in our study.

Funding: This work was supported by the National Health and Medical Research Council (NHMRC) of Australia and the Operational Infrastructure Support scheme of the Victorian State Government, Victoria, Australia. BAK is a NHMRC Senior Principal Research Fellow. ALG holds a NHMRC Career Development Fellowship and National Heart Foundation of Australia Future Leader Fellowship.

Disclosure Summary: The authors have nothing to disclose.

This article is protected by copyright. All rights reserved. 


\section{References}

1. Himms-Hagen J. Role of thermogenesis in the regulation of energy balance in relation to obesity. Canadian journal of physiology and pharmacology 1989;67:394-401

2. Rohlfs EM, Daniel KW, Premont RT, Kozak LP, Collins S. Regulation of the uncoupling protein gene (Ucp) by beta 1, beta 2, and beta 3-adrenergic receptor subtypes in immortalized brown adipose cell lines. J Biol Chem 1995;270:10723-32

3. Arch JR, Ainsworth AT, Cawthorne MA, Piercy V, Sennitt MV, Thody VE, Wilson C, Wilson S. Atypical beta-adrenoceptor on brown adipocytes as target for anti-obesity drugs. Nature 1984;309:163-5

4. Andersson KE, Arner A. Urinary bladder contraction and relaxation: physiology and pathophysiology. Physiol Rev 2004;84:935-86

5. Otsuka A, Shinbo H, Matsumoto R, Kurita Y, Ozono S. Expression and functional role of beta-adrenoceptors in the human urinary bladder urothelium. Naunyn Schmiedebergs Arch Pharmacol 2008;377:473-81

6. Arch JR. beta(3)-Adrenoceptor agonists: potential, pitfalls and progress. Eur J Pharmacol 2002;440:99-107

7. de Souza CJ, Hirshman MF, Horton ES. CL-316,243, a beta3-specific adrenoceptor agonist, enhances insulin-stimulated glucose disposal in nonobese rats. Diabetes 1997;46:1257-63

8. Xiao C, Goldgof M, Gavrilova O, Reitman ML. Anti-obesity and metabolic efficacy of the beta3-adrenergic agonist, CL316243, in mice at thermoneutrality compared to 22 degrees C. Obesity (Silver Spring) 2015;23:1450-9

9. Lafontaine JA, Day RF, Dibrino J, Hadcock JR, Hargrove DM, Linhares M, Martin KA, Maurer TS, Nardone NA, Tess DA, Dasilva-Jardine P. Discovery of potent and orally bioavailable heterocycle-based beta3-adrenergic receptor agonists, potential therapeutics for the treatment of obesity. Bioorganic \& medicinal chemistry letters 2007; $17: 5245-50$

10. Deng C, Paoloni-Giacobino A, Kuehne F, Boss O, Revelli JP, Moinat M, Cawthorne MA, Muzzin P, Giacobino JP. Respective degree of expression of beta 1-, beta 2- and 
beta 3-adrenoceptors in human brown and white adipose tissues. Br J Pharmacol 1996;118:929-34

11. Weyer C, Gautier JF, Danforth E, Jr. Development of beta 3-adrenoceptor agonists for the treatment of obesity and diabetes--an update. Diabetes Metab 1999;25:11-21

12. Takasu T, Ukai M, Sato S, Matsui T, Nagase I, Maruyama T, Sasamata M, Miyata K, Uchida H, Yamaguchi O. Effect of (R)-2-(2-aminothiazol-4-yl)-4'-\{2-[(2-hydroxy-2phenylethyl)amino]ethyl \} acetanilide (YM178), a novel selective beta3-adrenoceptor agonist, on bladder function. J Pharmacol Exp Ther 2007;321:642-7

13. Cypess AM, Weiner LS, Roberts-Toler C, Franquet Elia E, Kessler SH, Kahn PA, English J, Chatman K, Trauger SA, Doria A, Kolodny GM. Activation of human brown adipose tissue by a beta3-adrenergic receptor agonist. Cell metabolism 2015;21:33-8

14. Chapple CR, Amarenco G, Lopez Aramburu MA, Everaert K, Liehne J, Lucas M, Vik V, Ridder A, Snijder R, Yamaguchi O, Group BI. A proof-of-concept study: mirabegron, a new therapy for overactive bladder. Neurourol Urodyn 2013;32:1116-22

15. Chapple CR, Dvorak V, Radziszewski P, Van Kerrebroeck P, Wyndaele JJ, Bosman B, Boerrigter P, Drogendijk T, Ridder A, Van Der Putten-Slob I, Yamaguchi O, Dragon Investigator G. A phase II dose-ranging study of mirabegron in patients with overactive bladder. Int Urogynecol J 2013;24:1447-58

16. Chapple CR, Kaplan SA, Mitcheson D, Klecka J, Cummings J, Drogendijk T, Dorrepaal C, Martin N. Randomized double-blind, active-controlled phase 3 study to assess 12-month safety and efficacy of mirabegron, a beta(3)-adrenoceptor agonist, in overactive bladder. Eur Urol 2013;63:296-305

17. Khullar V, Amarenco G, Angulo JC, Cambronero J, Hoye K, Milsom I, Radziszewski P, Rechberger T, Boerrigter P, Drogendijk T, Wooning M, Chapple C. Efficacy and tolerability of mirabegron, a beta(3)-adrenoceptor agonist, in patients with overactive bladder: results from a randomised European-Australian phase 3 trial. Eur Urol 2013;63:283-95

18. Madamanchi A. Beta-adrenergic receptor signaling in cardiac function and heart failure. Mcgill J Med 2007;10:99-104 
19. Shin E, Ko KS, Rhee BD, Han J, Kim N. Different effects of prolonged beta-adrenergic stimulation on heart and cerebral artery. Integr Med Res 2014;3:204-10

20. Carey AL, Pajtak R, Formosa MF, Van Every B, Bertovic DA, Anderson MJ, Eikelis N, Lambert GW, Kalff V, Duffy SJ, Cherk MH, Kingwell BA. Chronic ephedrine administration decreases brown adipose tissue activity in a randomised controlled human trial: implications for obesity. Diabetologia 2015;58:1045-54

21. Rossanese M, Novara G, Challacombe B, Iannetti A, Dasgupta P, Ficarra V. Critical analysis of phase II and III randomised control trials (RCTs) evaluating efficacy and tolerability of a beta(3)-adrenoceptor agonist (Mirabegron) for overactive bladder (OAB). BJU Int 2015;115:32-40

22. Harris PA, Taylor R, Thielke R, Payne J, Gonzalez N, Conde JG. Research electronic data capture (REDCap)--a metadata-driven methodology and workflow process for providing translational research informatics support. J Biomed Inform 2009;42:377-81

23. Carey AL, Formosa MF, Van Every B, Bertovic D, Eikelis N, Lambert GW, Kalff V, Duffy SJ, Cherk MH, Kingwell BA. Ephedrine activates brown adipose tissue in lean but not obese humans. Diabetologia 2013;56:147-55

24. Loh RKC, Formosa MF, Eikelis N, Bertovic DA, Anderson MJ, Barwood SA, Nanayakkara S, Cohen ND, La Gerche A, Reutens AT, Yap KS, Barber TW, Lambert GW, Cherk MH, Duffy SJ, Kingwell BA, Carey AL. Pioglitazone reduces cold-induced brown fat glucose uptake despite induction of browning in cultured human adipocytes: a randomised, controlled trial in humans. Diabetologia 2018;61:220-30

25. Boon MR, Bakker LE, van der Linden RA, Pereira Arias-Bouda L, Smit F, Verberne HJ, van Marken Lichtenbelt WD, Jazet IM, Rensen PC. Supraclavicular skin temperature as a measure of $18 \mathrm{~F}-\mathrm{FDG}$ uptake by BAT in human subjects. PLoS One 2014;9:e98822

26. Lee P, Bova R, Schofield L, Bryant W, Dieckmann W, Slattery A, Govendir MA, Emmett L, Greenfield JR. Brown Adipose Tissue Exhibits a Glucose-Responsive Thermogenic Biorhythm in Humans. Cell metabolism 2016;23:602-9 
27. van der Lans AA, Vosselman MJ, Hanssen MJ, Brans B, van Marken Lichtenbelt WD. Supraclavicular skin temperature and BAT activity in lean healthy adults. J Physiol Sci 2016;66:77-83

28. Malik M, van Gelderen EM, Lee JH, Kowalski DL, Yen M, Goldwater R, Mujais SK, Schaddelee MP, de Koning P, Kaibara A, Moy SS, Keirns JJ. Proarrhythmic safety of repeat doses of mirabegron in healthy subjects: a randomized, double-blind, placebo-, and active-controlled thorough QT study. Clinical pharmacology and therapeutics 2012;92:696-706

29. Baskin AS, Linderman JD, Brychta RJ, McGehee S, Anflick-Chames E, Cero C, Johnson JW, O'Mara AE, Fletcher LA, Leitner BP, Duckworth CJ, Huang S, Cai H, Garraffo HM, Millo CM, Dieckmann W, Tolstikov V, Chen EY, Gao F, Narain NR, Kiebish MA, Walter PJ, Herscovitch P, Chen KY, Cypess AM. Regulation of Human Adipose Tissue Activation, Gallbladder Size, and Bile Acid Metabolism by a beta3Adrenergic Receptor Agonist. Diabetes 2018:

30. Chapple CR, Cardozo L, Nitti VW, Siddiqui E, Michel MC. Mirabegron in overactive bladder: a review of efficacy, safety, and tolerability. Neurourol Urodyn 2014;33:17-30

31. Krauwinkel W, van Dijk J, Schaddelee M, Eltink C, Meijer J, Strabach G, van Marle S, Kerbusch V, van Gelderen M. Pharmacokinetic properties of mirabegron, a beta3adrenoceptor agonist: results from two phase I, randomized, multiple-dose studies in healthy young and elderly men and women. Clin Ther 2012;34:2144-60

32. Mo W, Michel MC, Lee XW, Kaumann AJ, Molenaar P. The beta3 -adrenoceptor agonist mirabegron increases human atrial force through beta1 -adrenoceptors: an indirect mechanism? Br J Pharmacol 2017;174:2706-15

33. Hata JA, Williams ML, Koch WJ. Genetic manipulation of myocardial beta-adrenergic receptor activation and desensitization. J Mol Cell Cardiol 2004;37:11-21

34. Dehvari N, da Silva Junior ED, Bengtsson T, Hutchinson DS. Mirabegron: potential off target effects and uses beyond the bladder. Br J Pharmacol 2017:

35. Waldeck B, Widmark E. The interaction of ephedrine with beta-adrenoceptors in tracheal, cardiac and skeletal muscles. Clin Exp Pharmacol Physiol 1985;12:439-42 
36. Gauthier C, Rozec B, Manoury B, Balligand JL. Beta-3 adrenoceptors as new therapeutic targets for cardiovascular pathologies. Curr Heart Fail Rep 2011;8:184-92

37. Skeberdis VA, Gendviliene V, Zablockaite D, Treinys R, Macianskiene R, Bogdelis A, Jurevicius J, Fischmeister R. beta3-adrenergic receptor activation increases human atrial tissue contractility and stimulates the L-type Ca2+ current. J Clin Invest 2008;118:3219-27

38. Alexandre EC, Kiguti LR, Calmasini FB, Silva FH, da Silva KP, Ferreira R, Ribeiro CA, Monica FZ, Pupo AS, Antunes E. Mirabegron relaxes urethral smooth muscle by a dual mechanism involving beta3 -adrenoceptor activation and alpha1 -adrenoceptor blockade. Br J Pharmacol 2016;173:415-28

39. Michel MC. How beta3 -adrenoceptor-selective is mirabegron? $\mathrm{Br} \mathrm{J}$ Pharmacol 2016;173:429-30

40. Tasler S, Baumgartner R, Behr-Roussel D, Oger-Roussel S, Gorny D, Giuliano F, Ney P. An aryloxypropanolamine hbeta3-adrenoceptor agonist as bladder smooth muscle relaxant. Eur J Pharm Sci 2012;46:381-7

41. Vosselman MJ, van der Lans AA, Brans B, Wierts R, van Baak MA, Schrauwen P, van Marken Lichtenbelt WD. Systemic beta-adrenergic stimulation of thermogenesis is not accompanied by brown adipose tissue activity in humans. Diabetes 2012;61:3106-13

42. Dempsey PC, Sacre JW, Larsen RN, Straznicky NE, Sethi P, Cohen ND, Cerin E, Lambert GW, Owen N, Kingwell BA, Dunstan DW. Interrupting prolonged sitting with brief bouts of light walking or simple resistance activities reduces resting blood pressure and plasma noradrenaline in type 2 diabetes. J Hypertens 2016;34:2376-82

This article is protected by copyright. All rights reserved. 


\section{Table legend}

Table 1. M:F, male:female; BMI, body mass index; eVAT, estimated visceral adipose tissue; HOMA-IR, homeostatic model assessment of insulin resistance. Data are mean \pm SEM.

This article is protected by copyright. All rights reserved. 


\section{Figure legends}

Figure 1 CONSORT flow diagram illustrating the recruitment process through the phases of this multiple ascending dose study. SBP, systolic blood pressure

Figure 2 Time-course of energy expenditure (EE) $(\mathrm{kj} / \mathrm{hr})(\mathbf{a})$ immediately before $(0 \mathrm{~min})$ and after $(60-180 \mathrm{~min})$ treatment with single doses of mirabegron $(50,100,150$, and $200 \mathrm{mg})$. $\mathrm{EE}(\mathrm{kj} / \mathrm{hr})$ from (b) baseline ( 0 min, immediately prior to mirabegron ingestion (white bars)) to $180 \mathrm{~min}$ after ingestion (grey bars) of each mirabegron dose $(50,100,150$, and $200 \mathrm{mg}$, including individual data for each participant. Changes in EE from baseline vs 180 min post mirabegron ingestion within each dose in panel (b) were compared using Paired Student's ttests. Data are presented as mean \pm SEM. ${ }^{*} p \mathrm{~d} 0.05$ for difference between baseline vs 180 min post mirabegron ingestion within each dose. $50 \mathrm{mg} n=16,100 \mathrm{mg} n=12,150 \mathrm{mg} n=11,200$ $\operatorname{mg} n=9$.

Figure 3 Time-course of supraclavicular skin temperature (temp) $\left({ }^{\circ} \mathrm{C}\right)$ (a) immediately before $(0 \mathrm{~min})$ and after $(60-180 \mathrm{~min})$ treatment with a single dose of mirabegron $(50,100$, 150, and $200 \mathrm{mg})$. Supraclavicular skin temperature $\left({ }^{\circ} \mathrm{C}\right)$ from (b) baseline $(0 \mathrm{~min}$, immediately prior to mirabegron ingestion (white bars)) to 180 min after ingestion (grey bars) of a mirabegron dose $(50,100,150$, and $200 \mathrm{mg})$ including individual data for each participant. Changes in temp from baseline vs 180 min post mirabegron ingestion within each dose in panel (b) were compared using a Paired Student's t-test. Data are presented as 
mean \pm SEM. ${ }^{*} p \mathrm{~d} 0.05$ for difference between baseline vs 180 min post mirabegron ingestion within each dose. $50 \mathrm{mg} n=17,100 \mathrm{mg} n=13,150 \mathrm{mg} n=12,200 \mathrm{mg} n=10$.

Figure 4 Time-course of systolic blood pressure (SBP) (a), diastolic blood pressure (DBP) (c) and heart rate $(\mathrm{HR})(\mathbf{e})$ immediately before $(0 \mathrm{~min})$ and after $(30-180 \mathrm{~min})$ treatment with a single dose of mirabegron (50, 100, 150, and $200 \mathrm{mg})$. Changes (") in SBP (b) DBP (d) and HR (f) from immediately prior mirabegron ingestion $(0 \mathrm{~min})$ to $180 \mathrm{~min}$ after ingestion of the indicated mirabegron doses $(50,100,150$, and $200 \mathrm{mg})$, including data points for each individual. Changes in cardiovascular variables from baseline to $180 \mathrm{~min}$ post mirabegron ingestion for 100,150 and $200 \mathrm{mg}$ were compared to $50 \mathrm{mg}$ using a KruskalWallis ANOVA with Bonferroni-corrected Conover-Iman post-hoc analyses. Data are presented as mean \pm SEM. $50 \mathrm{mg} n=17,100 \mathrm{mg} n=13,150 \mathrm{mg} n=12,200 \mathrm{mg} n=10 .{ }^{*} p \mathrm{~d} 0.05$ for difference between indicated mirabegron doses and the $50 \mathrm{mg}$ dose.

This article is protected by copyright. All rights reserved. 
Table 1 - Participant baseline characteristics

\begin{tabular}{ll}
\hline Characteristic & \\
\hline $\mathrm{n}$ & 17 \\
M:F ratio & $11: 6$ \\
Age (years) & $24 \pm 1$ \\
Height $(\mathrm{cm})$ & $171 \pm 3$ \\
Weight $(\mathrm{kg})$ & $68 \pm 3$ \\
BMI $\left(\mathrm{kg} / \mathrm{m}^{2}\right)$ & $23 \pm 1$ \\
Waist:hip & $0.83 \pm 0.01$ \\
Total mass $(\mathrm{kg})$ & $67 \pm 3$ \\
Lean mass $(\mathrm{kg})$ & $47 \pm 3$ \\
Fat mass $(\mathrm{kg})$ & $18 \pm 2$ \\
Fat mass $(\%$ total mass) & $28 \pm 3$ \\
eVAT (g) & $290 \pm 41$ \\
Systolic blood pressure (mmHg) & $115 \pm 3$ \\
Diastolic blood pressure (mmHg) & $70 \pm 2$ \\
Heart rate (bpm) & $66 \pm 2$ \\
Insulin (pmol/l) & $42 \pm 4$ \\
Glucose (mmol/l) & $4.6 \pm 0.1$ \\
HOMA-IR & $1.2 \pm 0.1$ \\
\hline
\end{tabular}

This article is protected by copyright. All rights reserved. 
Figure 1

This article is protected by copyright. All rights reserved. 


\section{Enrolment}

Assessed for eligibility $(n=147)$

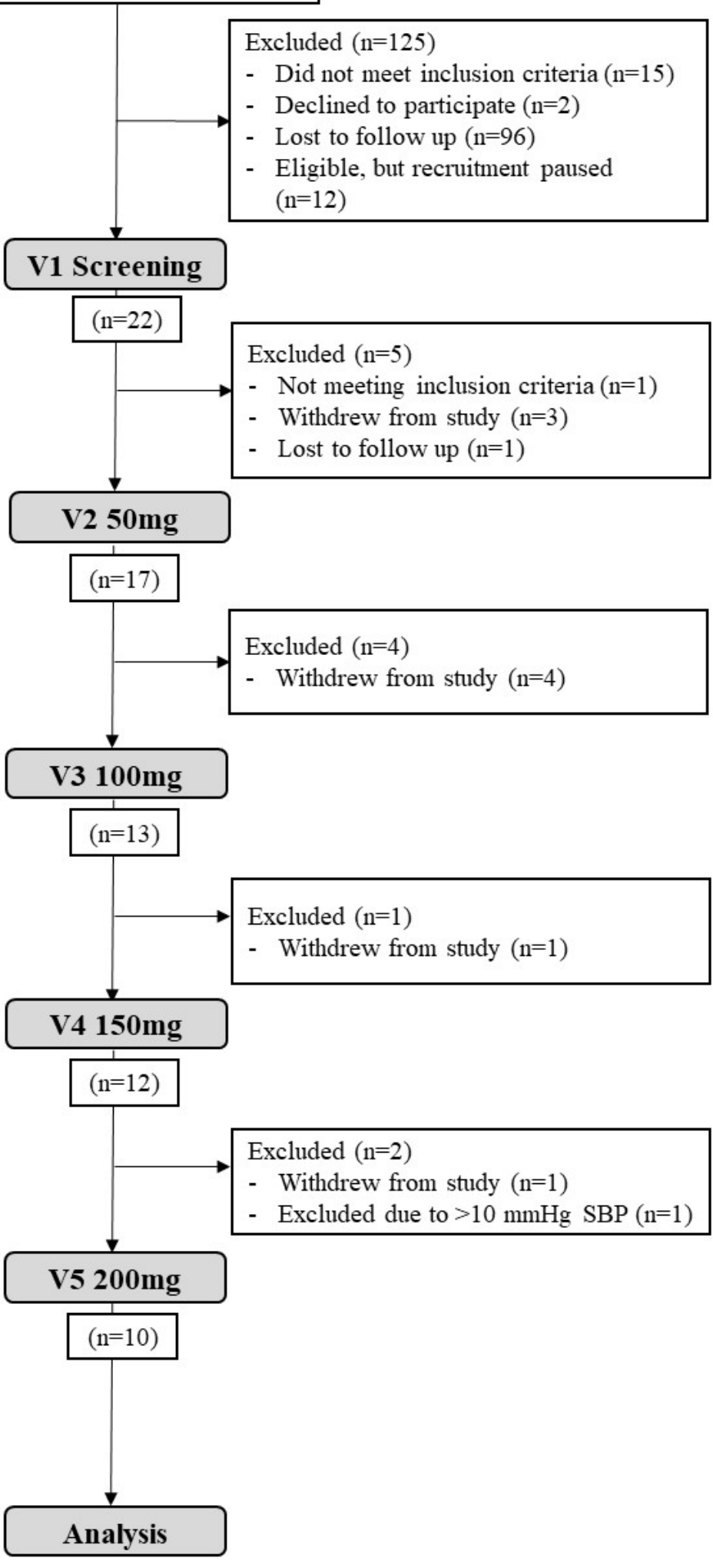

Analysed (varies per visit)

- V2: $(\mathrm{n}=17)$ for all variables except for energy expenditure $(\mathrm{n}=16)$.

- Energy expenditure excluded ( $\mathrm{n}=1)$ due to technical error

- V3: $(\mathrm{n}=13)$ for all variables except for energy expenditure $(\mathrm{n}=12)$.

- Energy expenditure excluded ( $\mathrm{n}=1)$ due to technical error

- V4: $(n=12)$ for all variables energy expenditure $(\mathrm{n}=11)$.

- Energy expenditure excluded ( $n=1)$ due to technical error

- V5: $(\mathrm{n}=10)$ for all variables energy expenditure $(\mathrm{n}=9)$.

- Energy expenditure excluded ( $\mathrm{n}=1)$ due to technical error 


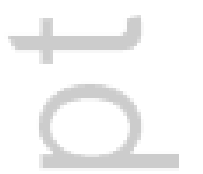

This article is protected by copyright. All rights reserved. 
Figure 2

(a)

$$
\begin{aligned}
& \stackrel{I}{c} \\
& \\
& w \\
& w
\end{aligned}
$$

(b)

This article is protected by copyright. All rights reserved. 
Figure 3

This article is protected by copyright. All rights reserved. 
(a)

i

○

E

$\frac{5}{y}$

o

$\frac{\pi}{\pi}$

$\frac{0}{3}$

$\frac{\pi}{0}$

$\frac{\pi}{2}$

ज

(b)

This article is protected by copyright. All rights reserved. 


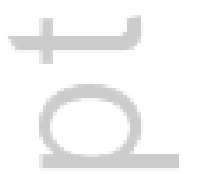

This article is protected by copyright. All rights reserved. 
Figure 4

This article is protected by copyright. All rights reserved. 


\section{(a)}

This article is protected by copyright. All rights reserved. 


\section{University Library}

\section{- M M N E R VA A gateway to Melbourne's research publications}

Minerva Access is the Institutional Repository of The University of Melbourne

Author/s:

Loh, RKC;Formosa, MF;La Gerche, A;Reutens, AT;Kingwell, BA;Carey, AL

Title:

Acute metabolic and cardiovascular effects of mirabegron in healthy individuals

Date:

2019-02-01

Citation:

Loh, R. K. C., Formosa, M. F., La Gerche, A., Reutens, A. T., Kingwell, B. A. \& Carey, A. L. (2019). Acute metabolic and cardiovascular effects of mirabegron in healthy individuals.

DIABETES OBESITY \& METABOLISM, 21 (2), pp.276-284. https://doi.org/10.1111/ dom. 13516.

Persistent Link:

http://hdl.handle.net/11343/284533 